\title{
Application of threshold vector error correction model (TVECM) in describing adjustment of interest rate of working capital credit to $\mathrm{BI}$ rate movement
}

\author{
Gama Putra Danu Sohibien* \\ Sekolah Tinggi Ilmu Statistik, Jl. Otto Iskandardinata 64 C, \\ Jakarta Timur 13330, Indonesia
}

\begin{abstract}
Knowledge about bank behavior in adjusting the interest rate to $\mathrm{BI}$ rate movement is important not only for debtors to make a decision to borrow money, but also for government to know whether $\mathrm{BI}$ rate as a monetary policy tool success in influencing the movement of interest rate. The approach used for analyzing the data in this paper is TVECM. The data used in this paper are interest rate of working capital credit of conventional bank and BI rate of January 2008 - July 2016. Bank is more agressive in correcting the disequilibrium by increasing the interest rate of working capital credit than decreasing it. Interest rate of working capital credit is significantly adjusted by bank approximately $64.95 \%$ of its disequilibrium when the disequilibrium is lower than 0.96 . When it is between 0.96 and 0.76 , interest rate of working capital credit will be adjusted approximately $11.87 \%$ of its disequilibrium. When it is higher than 0.76 , interest rate of working capital credit will be adjusted approximately $11.88 \%$ of its disequilibrium. Moderate interest rate of working capital credit based on $\mathrm{BI}$ rate consideration is between $1.74 \mathrm{BI}$ rate 0.96 and $1.74 \mathrm{BI}$ rate +0.76 . According to the selection criteria values, TVECM is better than VECM and VAR in modeling relationship between $\mathrm{BI}$ rate and interest rate of working capital.
\end{abstract}

Keywords: BI rate, interest rate, TVECM, working capital

Received: August 7, 2017; Accepted: September 12, 2017; Published online: October 27, 2017

*Corresponding author: gamaputra@stis.ac.id

Citation: Sohibien, G. P. D. (2017). Application of threshold vector error correction model (TVECM) in describing adjustment of interest rate of working capital credit to $\mathrm{BI}$ rate movement. Journal of Science and Science Education, 1(2), 31-43.

\section{Introduction}

The success of one country's development can be seen from its economic growth. Economic growth is the occurrence of development activities in the economy that cause the production of goods and services increase. The high and sustainable economic growth is a necessary condition for the process of economic development. The high economic growth aims to accelerate the achievement of the high level of people life. In addition, the high rate of economic growth can make our country to compete with other countries.

Bank Indonesia targets the economic growth of Indonesia is between 5.1 and 5.5 percent in 2017. The achievement of economic growth target is certainly through the process increasing production activities in all of the ecomonmic sectors. In increasing economic activities, company needs capital to add facilities and infrastructures that are physical investments to support economic activities, such as factories, office buildings, machinery, and other production equipment. Capital is the main source of economic growth. In other words, investment has the important role in spuring the achievment of the economic growth target. 
Sohibien: Application of threshold vector error correction model (TVECM) in describing adjustment of interest rate of working capital credit to BI rate movement

In general, the main source of investment in development countries including Indonesia is from banking credit (Harmanta, 2005). Some researches have shown that loans lended by bank can spur country's economic growth. Goldsmith (1969), Mc Kinon (1973), and Shaw (1973) found that surplus funds efficiently lended to deficit units will increase their production activities. The role of the banking sector towards economic growth is helping the business of debtors who need funds by lending them investment credit and working capital credit so that the business development of various sectors can be improved. Therefore, the banking sector becomes important because the bank have an intermediation role and greatly affect the economic growth of a country. When the credit lended by bank decreases, the economic growth can become slow because producers don't have enought capital to produce goods or services.

One of the types of credit lended by bank is working capital credit. Working capital credit is a credit facility provided by bank to facilitate the working capital in a business cycle with 1 year maximum period, such as for purchasing of production materials. During the period of January 2008December 2016, working capital credit was higher than investment and consumption credit. Percentage of working capital credit is always above 44 percent with an average of 48.53 percent during January 2008 to December 2016. This indicates that banks have a role more on productive financing, especially for increasing production in the short term than for consuming.

The bank as a lender will get benefit from the interest paid by borrowing company. Companies that get working capital credit can expand their business. For the government, the increase of working capital credit will have an impact on tax increase, unemployment reduction as a result of the expansion of the company's business, and export increase. All of these benefits will increase the economic growth.

One of the factors that affect the amount of credit disbursed by banks is the interest rate set by the bank. The increase of interest rate will decrease company's interest to borrow fund from the bank. The decrease of interest rate will increase company's interest to borrow fund from the bank. Based on some researches the interest rate which is too high will give an impact on declining the desire of investor to invest which could lead to decline in economic growth. On the other hand, the low interest rate of credit will also have an impact on the low profit received by bank from the credit lended services.

$\mathrm{BI}$ rate is one of the references used by commercial bank to decide the interst rate of working capital credit. BI Rate is the main policy instrument of Bank Indonesia to influence economic activity. If the economy is a downturn condition, BI will use monetary policy through lower interest rates to encourage economic activity. The decline in the $\mathrm{BI}$ rate will decrease the interest rates that will be responded by business actors to increase their credit demand. Thus the economic activity will increase. On the other hand, Bank as an institution with the biggest incomes gotten from interest rate will also pay attention to decide the appropriate interest rate so that the profit earned is also maximal.

Some researches on interest rates of credit have been done by many researchers, such as Setianto (2013), Ondieki \& Jagongo (2013), Listiyanto (2013), and Nugroho (2010). Of the many studies, there is no explanation about how the commercial banks will respond $\mathrm{BI}$ rate movement and if the adjustments of working capital interest rate are always same in each BI rate determination policies. In addition, there have been no researches that explain how the moderate interest rate with BI rate reference which can be used by banks to decide their interest rate of capital working credit.The approaches often used to explain the relationship between variables are cointegration and vector 
error correction model (VECM). The cointegration method was popularized by Engle \& Granger in 1987 (Gujarati, 2004). This approach is used to test if there is the long-run equilibrium relationship between economic variables. It can be used as a solution of spurious regresion problem, that is regression model with high $\mathrm{R}$ square value but there are no significant correlations between response variable and predictor variable. The VECM is a model developed to overcome the disequlibrium problem between variabels in the short term. This disequilibrium is often found in the behavior of relationships between economic variables. The VECM model includes adjustments to correct the disequibrium that occur so that the short-run dynamics of the variables within the system are affected by the disequibrium that occur.

The relationship between disequilibrium and short-run dynamics in VECM is assumed to be linear. Granger \& Terasvirta (1993) stated that the relationship between economic variables is usually not linear. Balke \& Fomby (1997) suggest that the adjustments to long-run equilibrium may differ in different economic circumstances. Stigler (2010) states that in macroeconomics, policy is often set based on targets, it means that intervention is done when deviations occur significantly from the target so that adjustments are not made instantly but it will be done after the deviation passes the threshold value. This is in contrast to the VECM which to correct disequilibrium in the same way. Thus, if the pattern of the relationship between deviation and short-term dynamics is nonlinear, VECM is not appropriate to describe the short-run relationship between variables. From all researches that have been done about the relationship between $\mathrm{BI}$ rate and credit interest rate in Indonesia, there have been no researches that explain the relationship by considering any nonlinear adjustment pattern that might occur to correct the disequilibrium.

Threshold model is based on principle that time series modeling process is signed by separating regimes which have different patern of relationship between variables. This model allows to do nonlinear adjustment to disequilibrium. This model has been used by some researchers, such as Esteve \& Prats (2010), Grasso (2010), and Aprilia et al. (2014). The concept of cointegration threshold as introduced by Balke \& Fomby (1997) has attracted practitioners' attention in explaining nonlinear adjustment patterns of relative prices and other variables. The basic idea of cointegration threshold model is that the model is formed by more than one time series model regime divided by value of error correction term (ECT). In other words the threshold effect on VECM model depends on the magnitude of disequilibrium on the long run system. The model used to make nonlinear adjustments to disequilibrium that occur in the short run is called the threshold VECM (TVECM).

Based on the consideration that the interest rate of working capital credit has an important role in determining the amount of working capital credit lended and the profit obtained by bank, some aims of this research are explain how the behavior of commercial banks in adjusting the interest rate of working capital credit to BI rate movement, knowing how the moderate interest rate of working capital credit with $\mathrm{BI}$ reference which can be used by banks to decide interest rate of working capital credit, and comparing performnace of TVECM, VECM, and VAR in modeling the relationship between interest rate of working capital and $\mathrm{BI}$ rate.

\section{Materials and Methods}

\subsection{Data Sources and Research Variables}

The data used in this research are $\mathrm{BI}$ rate and interest rate of working capital credit from January 2008 to July 2016. These data are secondary data which are sourced from the Indonesian Banking 
Statistics Publication published by Bank Indonesia (BI). Variables used in this research are $Y_{1 t}$ (BI rate) and $Y_{2 t}$ (interest rate of working capital credit).

\subsection{Steps on the Method}

Some steps that will be done to achieve the research objectives are as follows:

1. Testing stationarity of data

2. Selecting the optimum lag determined by the criteria of Akaike's information criterion (AIC), Schwarz information criterion (SIC), Hannan-Quinn Criterion (HQ), and Final Prediction Error (FPE).

3. Conducting cointegration testing

4. Testing the significance of existence of threshold with Lagrange Multiplier Test (LM test)

5. Creating a TVECM model.

6. Comparing the TVECM, VECM, and VAR models with the goodness criteria of AIC and FPE.

\subsection{VECM}

VECM is a VAR model created when inter-variables are mutually cointegrated. Enders (2004) states that variables in VECM are first difference variables in the VAR model distinguished by error correction term. In other word, variable in VECM is a cointegrated variable in the first order. The short-run relationship between variables is affected by deviations from long-run equilibrium known as cointegration term or error correction term. To discuss more about VECM, suppose we have a long-term relationship for two variables as follows:

$$
\hat{Y}_{1 t}=\beta_{0}+\beta_{1} Y_{2 t} \text {. }
$$

If $Y_{1 t}$ is at the equilibrium point of $Y_{2 t}$ then the equilibrium between $Y_{1 t}$ and $Y_{2 t}$ variable in Eq. (1) is satisfied. The equilibrium is rarely met in economic system. If $Y_{1 t}$ has a different value from its equilibrium value then the difference between the left and right sides of Eq. (1) is

$$
E C T=Y_{1 t}-\beta_{0}-\beta_{1} Y_{2 t} \text {. }
$$

ECT is called as disequilibrium error. The general form of VECM which includes the first difference variable up to the lag-p, is as follows:

$$
\begin{aligned}
& \Delta Y_{1 t}=a_{10}+a_{y 1}\left(Y_{1, t-1}-\beta_{0}-\beta_{1} Y_{2, t-1}\right)+\sum_{i=1}^{p} a_{11, i} \Delta Y_{1, t-i}+\sum_{i=1}^{p} a_{12, i} \Delta Y_{2, t-i}+\varepsilon_{y_{1, t}} \\
& \Delta Y_{2 t}=a_{20}+a_{y 2}\left(Y_{1, t-1}-\beta_{0}-\beta_{1} Y_{2, t-1}\right)+\sum_{i=1}^{p} a_{21, i} \Delta Y_{1, t-i}+\sum_{i=1}^{p} a_{22, i} \Delta Y_{2, t-i}+\varepsilon_{y_{2, t}}
\end{aligned}
$$

\subsection{TVECM}

The existence of the threshold in the model forms the VECM becomes as follows:

$$
\Delta y_{t}= \begin{cases}A_{1}^{T} y_{t-1}(\beta)+u_{t} & , \text { if } W_{t-1}(\beta) \leq \gamma, \\ A_{2}^{T} y_{t-1}(\beta)+u_{t} & , \text { if } W_{t-1}(\beta)>\gamma,\end{cases}
$$

where $A_{1}$ dan $A_{2}$ are matrix coefficients in both regimes, $A_{1}=A_{2}$ when there is no threshold, and $\gamma$ is threshold parameters. Model (5) can also be written as follows:

$$
\Delta y_{t}=A_{1}^{T} y_{t-1}(\beta) d_{1 t}(\beta, \gamma)+A_{2}^{T} y_{t-1}(\beta) d_{2 t}(\beta, \gamma)+\boldsymbol{u}_{-} t,
$$

where $d_{1 t}(\beta, \gamma)=I\left(W_{t-1}(\beta) \leq \gamma\right)$ and $d_{2 t}(\beta, \gamma)=I\left(W_{t-1}(\beta)>\gamma\right)$, in which $I$ is a indicator function.

Model (6) have two regimes which defined by error-correction term (ECT) value. The matrix coefficients $A_{1}$ and $A_{2}$ determine the dynamics of both regimes. Model (6) allows all coefficient (except the cointegration vector $B$ ) to switch between two regimes. The threshold effect exists if 
$0<P\left(W_{t-1} \leq \gamma\right)<1$. The value of $\gamma$ is determined by the limit $\pi_{0} \leq P\left(W_{t-1} \leq \gamma\right) \leq 1-\pi_{0}$, where $\pi_{0}>0$ is a trimming parameter.

\section{Results and Discussion}

From Figure 1, it can be seen that there is similarity of time series plot pattern between BI rate and interest rate of working capital credit. It indicates that BI Rate is related to working capital credit interest rate. In other words, the monetary policy instrument in the form of BI rate is indicated followed by interest rate movement of working capital credit. The highest BI rate occurred in October 2008 at 9.5 percent. This is due to the global crisis so that in minimizing the impact on the weakening of the rupiah against the dollar, $\mathrm{BI}$ raised $\mathrm{BI}$ rate to 9.5 percent to encourage foreign investors to invest by buying securities into financial instruments in Indonesia so that the flow of foreign capital into indonesia will appreciate rupiah exchange rate.

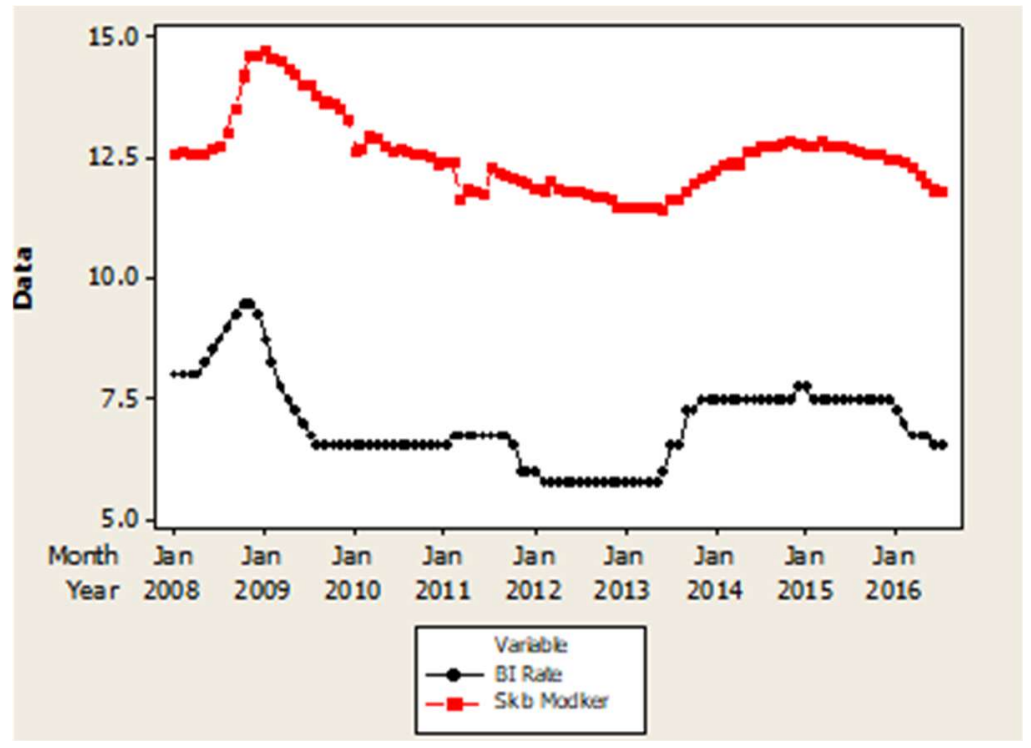

Figure 1. Time series plot of $\mathrm{BI}$ rate and interest rate of working capital.

Although BI rate in December 2008 has started to fall down to 9.25 percent, interest rates of working capital credit continue to increase even it's value in January 2009 is the highest value. The indirect decline in the interest rate of working capital credit can be caused by the economy situation that has not been so conducive. In addition, banks need time to recalculate their needs and organize strategies based on fund structures, unexpected expenses, and so on. Meanwhile, the lowest BI rate is at 5.75 percent in February 2012 to May 2013. The decrease of BI rate to 5.75 percent is step to spur Indonesia's economic growth amid declining global economic performance. This step looks successful when we look at the interest rates of working capital credit which become 11.29 percent in february 2012 and then decrease again 11.14 percent in June 2013. Low interest rates of working capital credit will increase the desire of producers to increase their production so that the economy becomes growth well. In June 2013, BI rose the BI rate become 6.00 percent and rose again until December 2015 become 7.50. It was also followed by an increase of interest rates of working capital credit. In January 2016 until July 2016, BI rate decreased become 6.50 percent. The working capital interest rate during the period of January 2016 until July 2016 also decreased to reach 11.79 percent. BI decreased BI rate in January-July 2016 because the economic condition was still slow. It was expected that $\mathrm{BI}$ rate decline was followed by the decrease of bank credit interest rate which could increase the credit distribution and spur economic growth. 


\subsection{Test of data stationarity}

The first step taken before forming TVECM model is to test the stationarity of the data. The cointegration test would be meaningful if all variables studied were not stationary and integrated at the same degree. Therefore, before conducting cointegration testing, it is necessary to test the stationarity of data on the variables to be studied. Table 1 shows the stationary test results of $\mathrm{BI}$ rate $\left(Y_{1}\right)$ and Interest Rate of Working Capital Credit $\left(Y_{2}\right)$ for the original data.

Table 1. Test of level data stasionarity.

\begin{tabular}{ccccc}
\hline Variable & Test & Null hypothesis (Ho) & p-value & Conclusion \\
\hline \multirow{2}{*}{$Y_{1}$} & ADF & not stasioner & 0.1153 & Fail to Reject Ho \\
& PP & not stasioner & 0.4082 & Fail to Reject Ho \\
\hline \multirow{2}{*}{$Y_{2}$} & ADF & not stasioner & 0.4920 & Fail to Reject Ho \\
& PP & not stasioner & 0.5341 & Fail to Reject Ho \\
\hline
\end{tabular}

Source: Result of data processing by using Eviews 8.

According to Table 1, it can be seen that $p$-value of the ADF and PP test for variables $Y_{1}$ and $Y_{2}$ are greater than 0.05 . It gives the decision that the null hypothesis is not rejected with a significant level of 5 percent, which means that BI rate and interest rate of working capital credit are not stationary in significant level of 5 percent. The next step is to test stationary of two variables after first differencing. The result of stationary test is presented in Table 2.

Table 2. Test of first difference data stationarity.

\begin{tabular}{ccccc}
\hline Variable & Test & Null hypothesis (Ho) & p-value & Conclusion \\
\hline \multirow{2}{*}{$Y_{1}$} & ADF & not stasioner & 0.0005 & Reject Ho \\
& PP & not stasioner & 0.0000 & Reject Ho \\
\hline \multirow{2}{*}{$Y_{2}$} & ADF & not stasioner & 0.0002 & Reject Ho \\
& PP & not stasioner & 0.0000 & Reject Ho \\
\hline
\end{tabular}

Source: Result of data processing by using Eviews 8 .

According to Table 2, it can be seen the result of stationarity data test of variables $Y_{1}$ and $Y_{2}$ in the first difference form. P-value of the ADF and PP test for variables $Y_{1}$ and $Y_{2}$ in the first difference form are greater than 0,05 . It gives the decision that the null hypothesis is rejected with a significant level of 5 percent, which means that the first difference of BI rate and interest rate of working capital credit are stationary in significant level of 5 percent. Thus, cointegration testing between the interest rate of working capital credit and $\mathrm{BI}$ rate can be continued.

\subsection{Optimum lag length}

The determination of optimum lag length is required for being used on granger causality test and TVECM formation. Table 3 presents the results of optimum lag lengths obtained using AIC, SIC, HQ, and FPE criteria.

From three criteria (FPE, AIC, and HQ), we can conclude that the optimum lag length chosen in this research is 3 . It indicates that current interest rate of working capital credit and $\mathrm{BI}$ rate still give effect on the interest rate of working capital credit and BI rate up to three months ahead. This conclusion is also supported by the opinion of Venus Khim and Liew (2004) that said that AIC and FPE criteria can minimize the occurrence of underestimation and maximize the opportunity to obtain the actual lag length for small samples $(T<120)$. 
Table 3. Test of optimum lag length.

\begin{tabular}{ccccc}
\hline \multirow{2}{*}{ Lag } & \multicolumn{4}{c}{ BI rate vs interest rate of capital working credit } \\
\cline { 2 - 5 } & FPE & AIC & SIC & HQ \\
\hline 1 & 0.000662 & -1.645164 & $-1.482826^{*}$ & -1.579592 \\
2 & 0.000617 & -1.715864 & -1.445301 & -1.606576 \\
3 & $0.000563^{*}$ & $-1.806969^{*}$ & -1.428180 & $-1.653966^{*}$ \\
4 & 0.000571 & -1.794294 & -1.307280 & -1.597576 \\
5 & 0.000580 & -1.778968 & -1.183729 & -1.538535 \\
6 & 0.000623 & -1.708991 & -1.005526 & -1.424843 \\
7 & 0.000673 & -1.633110 & -0.821420 & -1.305247 \\
8 & 0.000691 & -1.609770 & -0.689855 & -1.238191 \\
\hline
\end{tabular}

Source: Result of data processing by using Eviews 8 .

\subsection{Granger causality test}

Granger causality test in this research is done to see the form of causality relationship that occurs between $\mathrm{BI}$ rate change and change of interest rate of working capital credit, whether one way causal relationship, two way, or no relationship. The test uses an $\mathrm{F}$ test statistic. Decision rejected or not the null hypothesis can be done by looking at the $p$-value. If $p$-value is less than the significant level $(\alpha)$, the decision is to reject Ho. Table 4 presents the results of Granger causality test.

Tabel 4. Granger causality test between BI rate and interest rate of working capital credit.

\begin{tabular}{|c|c|c|c|}
\hline Causality test & Null hypothesis & F-statistic & p-value \\
\hline $\begin{array}{l}\text { The change of } \mathrm{BI} \text { rate } \\
\text { and the change of }\end{array}$ & $\begin{array}{l}\text { The change of } \mathrm{BI} \text { rate doesn't cause the change } \\
\text { of interest rate of working capital credit }\end{array}$ & 3.768 & 0.0134 \\
\hline $\begin{array}{c}\text { interest rate of } \\
\text { working capital credit }\end{array}$ & $\begin{array}{l}\text { The change of interest rate of working capital } \\
\text { credit doesn't cause the change of BI rate }\end{array}$ & 4.522 & 0.0053 \\
\hline
\end{tabular}

According to Table 4 , it can be seen that $\mathrm{p}$-value is less than 0.05 for all null hypotheses. The decision for both hypotheses is to reject $\mathrm{Ho}$. This indicates that the change of $\mathrm{BI}$ rate influences the change of interest rate of working capital credit, and vice versa the change of interest rate of working capital credit affect the change of BI rate. Thus the causality relationship that occurs between the change of $\mathrm{BI}$ rate and the change of interest rate of working capital credit is two-way causality relationship (bilateral causality).

\subsection{Cointegration test and TVECM}

Having shown empirically that the change of $\mathrm{BI}$ rate and the change of interest rate of working capital credit interest has two-way causality relationship, the next step is to conduct cointegration test to see whether there is a long-run equilibrium relationship between $\mathrm{BI}$ rate and interest rate of working capitalcredit. Long-run equilibrium relationships are required to avoid spurious regression problems caused by non-stationary data. Cointegration test was done by Engel-Granger procedure. The first step is to form regression model was formed. After that residual of regression model was tested if it had been stationer or not. The following regression model is formed:

$$
Y_{2 t}=1.77 Y_{1 t}+e_{t}
$$

Table 5 shows that residuals formed from the regression model are stationary at the level because p-value resulted by this model is less than 5 percent. It shows that there is a long-run equilibrium relationship between $\mathrm{BI}$ rate and interest rate of working capital credit. 
Sohibien: Application of threshold vector error correction model (TVECM) in describing adjustment of interest rate of working capital credit to BI rate movement

Table 5. Stasionary test result of residual regression model.

\begin{tabular}{ccc}
\hline Test & Null hypothesis & p-value \\
\hline ADF & Residual is not stationary & 0.0047 \\
PP & Residual is not stationary & 0.0296 \\
\hline
\end{tabular}

Source: Result of data processing by using Eviews 8 .

Having known that there is a long-run equilibrium relationship between $\mathrm{BI}$ rate and interest rate of working capital credit, the next step is testing significance of threshold existence. This test is important to decide whether TVECM can be used to describe relationship between $\mathrm{BI}$ rate and interest rate of working capital credit. Hypothesis which used in this test is: $\mathrm{H}_{0}$ : model is linear VECM and $\mathrm{H}_{1}$ : model is TVECM.

Significance test of threshold was done by using SupLM. The result of significance test of the threshold existence obtained by using software R 3.1.0 is presented in Table 6. According to Table 6 , test statistic value obtained is 27.35709 with $p$-value equal to 0.044 . It shows that the modeling of relationship between BI rate and interest rate of working capital credit can be continued by using threshold. Beside that, it shows that there is different correction from the interest rate of the working capital credit or BI rate to respond disequilibrium between those two variables at a certain threshold limit. Thus TVECM model is appropriate to form.

Table 6. The test result of threshold existence significance.

\begin{tabular}{ccccc}
\hline Signifiance level & Critical value & Test statistics & p-value & Decision \\
\hline $5 \%$ & 26.988 & \multirow{2}{*}{27.357} & \multirow{2}{*}{0.044} & Reject $\mathrm{H}_{0}$ \\
$10 \%$ & 25.453 & & Reject $\mathrm{H}_{0}$ \\
\hline
\end{tabular}

Source: Result of data processing by using R 3.1.0.

Table 7. Selection criteria of model (AIC and BIC) according to the form of TVECM.

\begin{tabular}{ccc}
\hline TVECM & AIC & BIC \\
\hline 2 regimes & -757.896 & -672.260 \\
3 regimes & -802.148 & -803.913 \\
\hline
\end{tabular}

Source: Result of data processing by using Eviews 8 .

A model which will be used to analyze behaviour of interest rate of working capital credit is a model which results the smallest AIC and BIC. TVECM with three regimes is the best model to describe relationship between $\mathrm{BI}$ rate and interest rate of working capital credit.

Threshold values $\left(\gamma_{1}\right.$ and $\left.\gamma_{2}\right)$ that divide model to become three regimes are -0.96 and 0.76 . Based on Table 8 TVECM with 3 regimes for relationship between interest rate of working capital credit $\left(Y_{2}\right)$ and $\mathrm{BI}$ rate $\left(Y_{1}\right)$ can be written as follows:

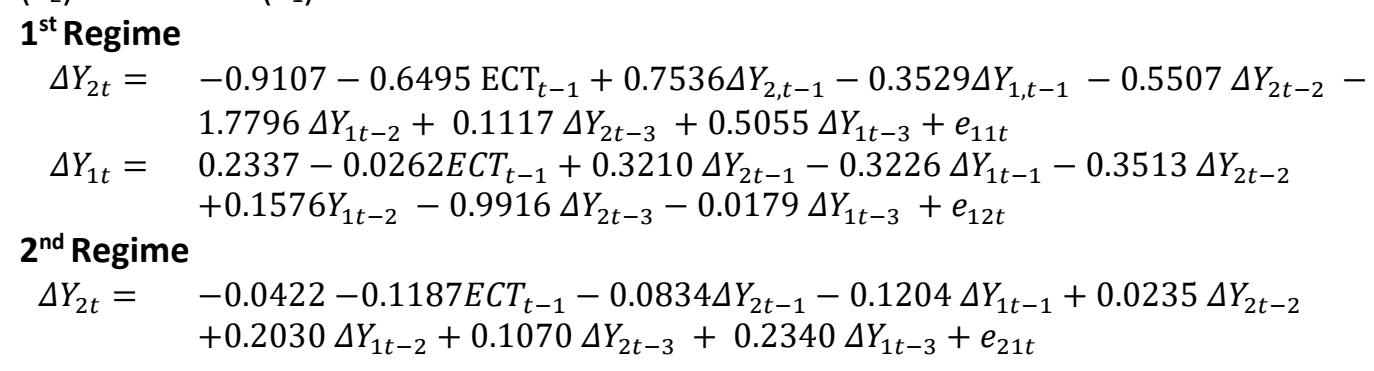




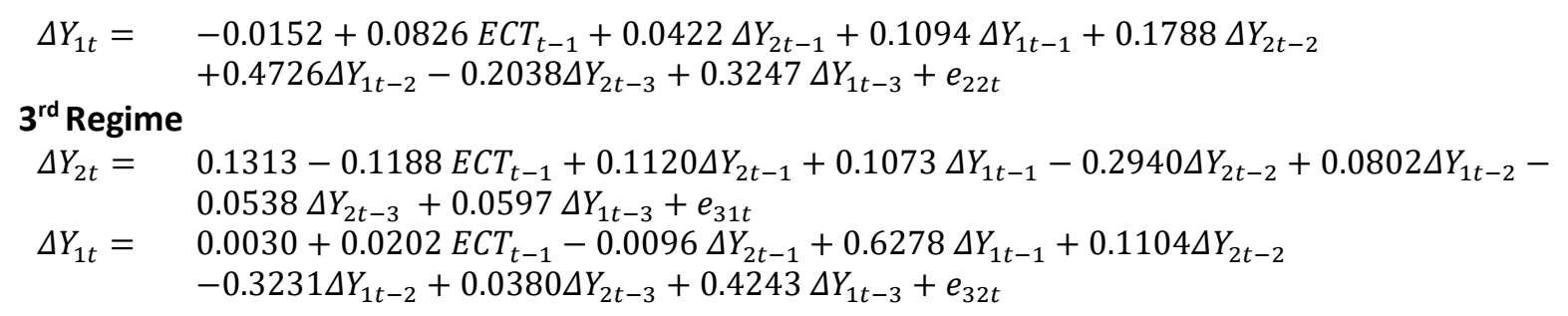

Table 8. Parameter coefficient estimation of 3 regimes TVECM for relationship between BI rate $\left(Y_{1}\right)$ and interest rate of working capital credit $\left(Y_{2}\right)$.

\begin{tabular}{ccccccc}
\hline \multirow{2}{*}{ Variabel } & \multicolumn{2}{c}{ Rezim 1 } & \multicolumn{2}{c}{ Rezim 2 } & \multicolumn{2}{c}{ Rezim 3 } \\
\cline { 2 - 7 } & $\Delta Y_{2 t}$ & $\Delta Y_{1 t}$ & $\Delta Y_{2 t}$ & $\Delta Y_{1 t}$ & $\Delta Y_{2 t}$ & $\Delta Y_{1 t}$ \\
\hline \multirow{2}{*}{ ECT $_{t-1}$} & -0.6495 & -0.0262 & -0.1187 & 0.0826 & -0.1188 & 0.0202 \\
& $(0.0007)^{* * *}$ & $(0.8788)$ & $(0.0284)^{*}$ & $(0.1002)$ & $(0.0456)^{*}$ & $(0.7119)$ \\
Constant & -0.9107 & 0.2337 & -0.0422 & -0.0152 & 0.1313 & 0.0030 \\
& $(0.0049)^{* *}$ & $(0.4283)$ & $(0.0695)$. & $(0.4798)$ & $(0.1584)$ & $(0.9719)$ \\
$\Delta Y_{2, t-1}$ & 0.7536 & 0.3210 & -0.0834 & 0.0422 & 0.1120 & -0.0096 \\
& $(0.0579)$. & $(0.3825)$ & $(0.5289)$ & $(0.7331)$ & $(0.5496)$ & $(0.9564)$ \\
$\Delta Y_{1, t-1}$ & -0.3529 & -0.3226 & -0.1204 & 0.1094 & 0.1073 & 0.6278 \\
& $(0.6766)$ & $(0.6830)$ & $(0.3269)$ & $(0.3400)$ & $(0.5830)$ & $(0.0009)^{* * *}$ \\
$\Delta Y_{2, t-2}$ & -0.5507 & -0.3513 & 0.0235 & 0.1788 & -0.2940 & 0.1104 \\
& $(0.3152)$ & $(0.4920)$ & $(0.8596)$ & $(0.1531)$ & $(0.0992)$. & $(0.5042)$ \\
$\Delta Y_{1, t-2}$ & -1.7796 & 0.1576 & 0.2030 & 0.4726 & 0.0802 & -0.3231 \\
& $(0.0396)^{*}$ & $(0.8431)$ & $(0.1079)$ & $(0.0001)^{* * *}$ & $(0.7283)$ & $(0.1367)$ \\
$\Delta Y_{2, t-3}$ & 0.1117 & -0.9916 & 0.1070 & -0.2038 & -0.0538 & 0.0380 \\
& $(0.8839)$ & $(0.1677)$ & $(0.4013)$ & $(0.0892)$. & $(0.7699)$ & $(0.8249)$ \\
$\Delta Y_{1, t-3}$ & 0.5055 & -0.0179 & 0.2340 & 0.3247 & 0.0597 & 0.4243 \\
& $(0.1209)$ & $(0.9528)$ & $(0.2148)$ & $(0.0670)$. & $(0.7545)$ & $(0.0194)^{*}$ \\
\hline
\end{tabular}

Source: Result of data processing by using Eviews 8.

Description: Values in parentheses are $p$-value $\mathrm{ECT}_{t-1}=Y_{2, t-1}-1.74 Y_{1, t-1}$

Threshold Values resulted are -0.96 and 0.76

Percentage of observations in each regime are $10.1 \%, 45.5 \%$, and $44.4 \%$

(.) Significant with a significance level of 10 percent

(*)Significant with a significance level of 5 percent

$(* *)$ Significant with a significance level of 1 percent

$(* * *)$ Significant with a significance level of 0.05 percent

The way of Interest rate of working capital credit and $\mathrm{BI}$ rate in responding the disequilibrium between $\mathrm{BI}$ rate and interest rate of working capital credit are different between regimes. Three regimes in TVECM is based on 2 threshold values. Two threshold values used are -0.96 and 0.76 . The first regime shows how interest rate of working capital credit and BI rate to adjust when the disequilibrium of one month before is less than -0.96 . The second regime shows how interest rate of working capital credit and BI rate to adjust when disequilibrium of one month before is more than or equal to -0.96 and less than 0.76 . The third regime shows how interest rate of working capital credit and $\mathrm{BI}$ rate to adjust when the disequillbrium of one month before is more than or equal to 0.76 .

Empirically, we can be seen how interest rate of working capital credit and $\mathrm{BI}$ rate to respond disequilibrium occurred among two variables. Coefficients of $\mathrm{ECT}_{t-1}$ describe how big variable of interest rate of working capital credit and $\mathrm{BI}$ rate do adjustment when there is disequilibrium in the short term. It means that when $\mathrm{ECT}_{t-1}$ coefficient is significant, all variables in have cointegration or 
Sohibien: Application of threshold vector error correction model (TVECM) in describing adjustment of interest rate of working capital credit to BI rate movement

long-run equilibrium because when disequilibrium occurred in short-term, one or two of variables will make adjustment to the long-run equillibrium.

According to the Table 8, we can see that $\mathrm{ECT}_{t-1}$ coefficient is significant only in equation of interest rate of working capital credit. It shows that when disequilibrium between interest rate of working capital credit and BI rate occurred, interest rate of working capital credit variable is only variable that significantly respond disequilibrium to correct it. Beside that, significant $\mathrm{ECT}_{t-1}$ shows that there is long-run equilibrium between interest rate of working capital credit and BI rate. The way of adjustment of interest rate of working capital credit is different in each regimes.

$E C T_{t-1}$ coefficient in the equation of interest rate of working capital credit in first regime is -0.96 . It can be interpreted that when disequilbrium is less than $-0,96$, interest rate of working capital credit will respond by correcting 64.95 percent of disequilibrium that occurred. This correction will increase interest rate of working capital credit in the $t$ period so that it's will lead to log-run equilibrium.

In the second regime, $\mathrm{ECT}_{t-1}$ coefficient has a meaning when disequilibrium is more than or equal to -0.96 and less than 0.76 adjustment of interest rate of working capital credit done by correcting 11.87 percent of disequilibrium that occurs. While in the third regime, $\mathrm{ECT}_{t-1}$ coefficient describes the adjustment of interest rate of working capital credit by correcting 11.88 percent of disequilibrium that occurs.

When we compare $\mathrm{ECT}_{t-1}$ value of interest rate of working capital credit in each regime, we can see that there is significant difference between $\mathrm{ECT}_{t-1}$ value of the first regime (64.95 percent) and $E C T_{t-1}$ value of the third regime (11.88 percent). It illustrates that banks are more aggressive to respond disequilibrium by increasing interest rate of working capital credit when the real interst rate of working capital credit is lower than the value of interest rate of working capital credit obtained from long-run equations. When actual interest rates of working capital credit are higher than interest rates of working capital credit obtained from long-run equations, banks are not too aggressive to decrease interest rates of working capital credit.

The effect of change of interest rate of working capital credit and $\mathrm{BI}$ rate in previous period to change of interest rate of working capital credit and $\mathrm{BI}$ rate change at this time can be seen from

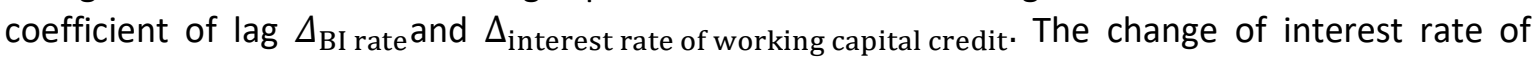
working capital credit on the first regime was significantly influenced by the change of interest rate of working capital credit in one month before and the change of BI rate in two months before. In the second regime, the change of $\mathrm{BI}$ rate were significantly affected by the changes of $\mathrm{BI}$ rate in 2 and 3 months before. While in the third regime, the change of interest rate of working capital credit is influenced by the interest rate of working capital credit two months before and the change of $\mathrm{BI}$ rate influenced significantly by the change of $\mathrm{BI}$ rate 1 and 3 months before.

By assuming that moderate regime is in the second regime that describes condition in which disequilibrium between interest rate of working capital credit and $\mathrm{BI}$ rate is not too big and not too small. In this regime, the difference between actual interest rate of working capital credit and interest rate of working capital credit obtained from long run equity is -0.96 until 0.76 . So moderate interest rate of working capital credit is between $1.74 \mathrm{BI}$ rate -0.96 and $1.74 \mathrm{BI}$ rate +0.76 . 


\subsection{Comparison of TVECM, VECM, and VAR}

In this research, TVECM will be compared with VECM and VAR in modeling the relationship of interest rate of working capital credit and $\mathrm{BI}$ rate. The best model selection criteria was done by using AIC, BIC, and SBC.

The best VECM models:

$$
\begin{aligned}
& \Delta Y_{2 t}=0.0050-0.0488 \mathrm{ECT}_{t-1}+0.1242 \Delta Y_{2 t-1}-0.0224 \Delta Y_{1 t-1}-0.0969 \Delta Y_{2 t-2}+ \\
& 0.2077 \Delta Y_{1 t-2}+0.0199 \Delta Y_{2 t-3}+0.0981 \Delta Y_{1 t-3}+e_{1 t} \\
& \Delta Y_{1 t}=\quad-0.0076+0.0079 \mathrm{ECT}_{t-1}-0.0200 \Delta Y_{2 t-1}+0.3465 \Delta Y_{1 t-1}+0.0032 \Delta Y_{2 t-2} \\
& +0.3186 \Delta Y_{1 t-2}-0.2767 \Delta Y_{2 t-3}+0.0981 \Delta Y_{1 t-3}+e_{2 t}
\end{aligned}
$$

where $\mathrm{ECT}_{t-1}=Y_{2, t-1}-1.772528 Y_{1, t-1}$.

The VAR model:

$$
\begin{aligned}
\Delta Y_{2 t}=\quad & 0.346285 \Delta Y_{1 t-1}-0.031278 \Delta Y_{2 t-1}+0.310363 \Delta Y_{1 t-2}-0.005271 \Delta Y_{2 t-2} \\
& -0.289473 \Delta Y_{1 t-3}+e_{1 t} \\
\Delta Y_{1 t}=\quad & 0.194440 \Delta Y_{2 t-1}-0.005037 \Delta Y_{1 t-1}-0.035982 \Delta Y_{2 t-2}+0.265927 \Delta Y_{1 t-2} \\
& +0.107110 \Delta Y_{2 t-3}+0.153644 \Delta Y_{1 t-3}+e_{2 t}
\end{aligned}
$$

Table 9. The best model selection criteria.

\begin{tabular}{cccc}
\hline Criteria & TVECM & VECM & VAR \\
\hline AIC & -802.148 & -737.449 & -740.444 \\
BIC & -803.913 & -725.864 & -728.115 \\
SBC & -802.148 & -706.307 & -709.303 \\
\hline
\end{tabular}

Source: Result of data processing by using Eviews 8.

From Table 9, we can see that three used criteria give the smallest value for TVECM. It means that the best model which can be used to describe relationship between $\mathrm{BI}$ rate and interest rate of working capital credit is TVECM. Figure 2 presents a comparison between actual time series data plot of interest rate of working capital credit and interest rate of working capital credit obtained from TVECM.

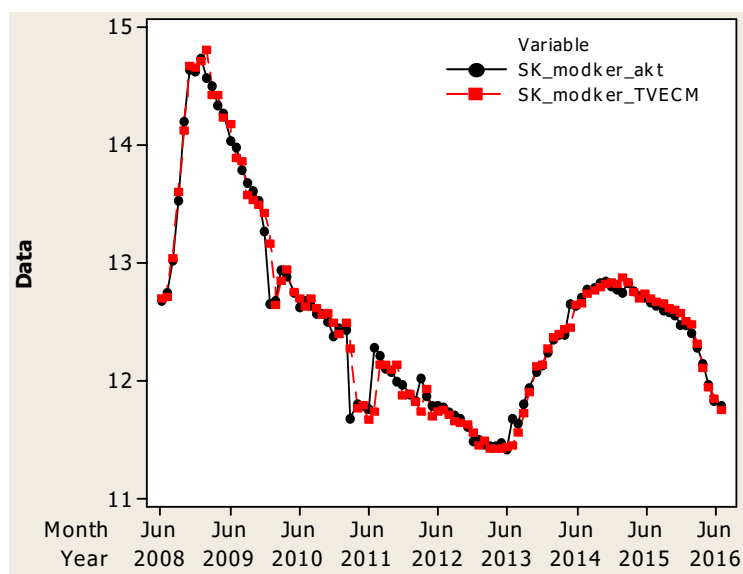

(a) Interest Rate of working capital Credit

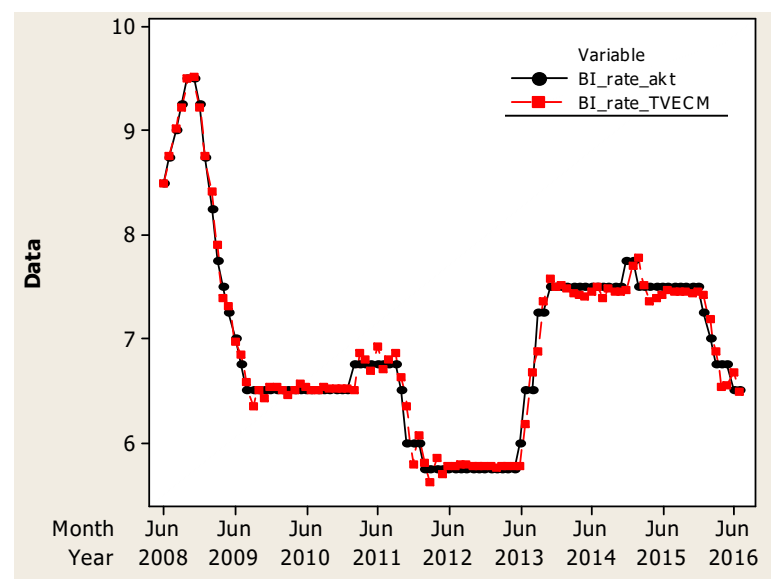

(b) BI Rate

Figure 2. Comparison between the actual time series data plot of interest rate of working capital credit and interest rate of working capital credit obtained from TVECM. 
Sohibien: Application of threshold vector error correction model (TVECM) in describing adjustment of interest rate of working capital credit to BI rate movement

\section{Conclusion}

According to the time series plot, there is relationship between interest rate of working capital credit and $\mathrm{BI}$ rate. This is supported by the results of granger causality test which concludes that the relationship between changes in $\mathrm{BI}$ rate and changes in interest rates of working capital credit is two-way causality relationship. So it can be said that the BI rate as a tool of monetary policy succeeded in influencing the movement of interest rates of working capital credit.

$\mathrm{BI}$ rate and interest rate of working capital credit also have a significant long-run equilibrium relationship. When there is a disequilibrium, interest rate of working capital credit will make adjustments to return to the long-run equilibrium.

TVECM modeling is appropriate to use in this case. There is different correction from the interest rate of the working capital credit or $\mathrm{BI}$ rate to respond the disequilibrium that occurs between those two variables at a certain threshold limit. When disequlibrium occurs less than -0.96 , interest rate of working capital credit will be adjusted by correcting 64.95 percent of disequilibrium. When disequilibrium is more than or equal to -0.96 and less than 0.76 adjustment of interest rate of working capital credit done by correcting 11.87 percent of disequilibrium. While the adjustment of interest rate of working capital credit is by correcting 11,88 percent of disequilibrium, when disequilibrium is more than or equal to 0.76 .

Banks are more aggressive to respond disequilibrium by increasing interest rate of working capital credit when the actual interst rate of working capital credit is lower than the value of interest rate of working capital credit obtained from long-run equations. When actual interest rates of working capital credit are higher than interest rates of working capital credit obtained from long-run equations, banks are not too aggressive to decrease interest rates of working capital credit. Moderate interest rate of working capital credit based on $\mathrm{BI}$ rate consideration is between $1.74 \mathrm{BI}$ rate -0.96 to less than $1.74 \mathrm{BI}$ rate +0.76 . By using three selection criteria (AIC, SBC, BIC), it can be showed that TVECM is the best model than VECM and VAR to describe relationship between $B I$ rate and

\section{Acknowledgment}

I would like to thank to my institution, Sekolah Tinggi Ilmu Statistik. I get support from Sekolah Tinggi IImu Statistik to present my research in IConSSE.

\section{References}

Aprilia, A., Anindita, R., Syafrial, Tsai, G., \& Hsien, L. (2014). Threshold cointegration pada pasar jagung di Indonesia, AGRISE, 14(1), 1-13.

Balke, N. S., \& Fomby, T. B. (1997). Threshold cointegration. International Economic Review, 38, 627-645.

Enders, W. (2004). Applied econometric time series (2nd ed.). New York: John Wiley \& Sons Inc.

Esteve, V., \& Prats, M. A. (2010). Threshold cointegration and nonlinear adjustment between stock prices and dividens. Applied Economics Letters, 17, 405-410.

Granger, C. W. J, \& Terasvirta (1993). Modelling nonlinear economic relationships (Advanced texts in econometrics). Oxford: Oxford University Press 
Grasso, M. (2010). Three-regime threshold error correction models and the law of one price: The case of European electricity markets. Working Paper n.30.

Gujarati, D. (2004). Basic econometric. New York: McGraw-Hill.

Harmanta, E. M. (2005, June). Disintermediasi fungsi perbankan di Indonesia pasca krisis 1997: Faktor permintaan atau penawaran kredit, sebuah pendekatan dengan model disequilibrium. Buletin Ekonomi Moneter dan Perbankan, p. 51.

Listiyanto. (2013). Analisis kelakuan dan faktor-faktor uang mempengaruhi tingkat suku bunga perbankan di Indonesia. Jurnal Kebijakan Ekonomi, 8(2), 26-36.

Nugroho, H. N. (2010). Pengaruh kebijakan BI rate terhadap suku bunga kredit investasi bank umum periode Juli 2005-Desember 2009 (Unpublished master's thesis). Universitas Indonesia.

Ondieki, D. N., \& Jagongo, A.. (2013). Effect of lowering central bank rate on bank's prime rate: An analysis of Kenyan commercial banks. International Journal of Humanities and Social Science, 3(20), 207-2014.

Setianto, T. B. (2013). Faktor-faktor yang mempengaruhi suku bunga kredit investasi pada sektor perbankan di Indonesia periode 2006-2012. Jurnal MIX, 3(2), 133-145.

Stigler, M. (2010). Threshold cointegration: Overview and implementation in R. Retrieved from http://cran.rproject.org/package=tsDyn 